\title{
Sequestration of carbon dioxide using ground granulated blast furnaces slag and kaolin mixtures
}

\author{
Mohammed A.M.A. ${ }^{1 *}$, Yunus N.Z.M. ${ }^{1}$, Hezmi M.A. ${ }^{1}$, Rashid A.S.A. ${ }^{2}$ \\ ${ }^{1}$ Department of Geotechnics and Transportation, School of Civil Engineering, Universiti Teknologi Malaysia, Johor, Malaysia \\ ${ }^{2}$ Centre of Tropical Geoengineering (GEOTROPIK), School of Civil Engineering, Universiti Teknologi Malaysia, Johor, Malaysia \\ Received: 16/12/2020, Accepted: 07/01/2021, Available online: 15/01/2021 \\ *to whom all correspondence should be addressed: e-mail: khatib.kaka@yahoo.com \\ https://doi.org/10.30955/gnj.003487
}

\section{Graphical abstract}

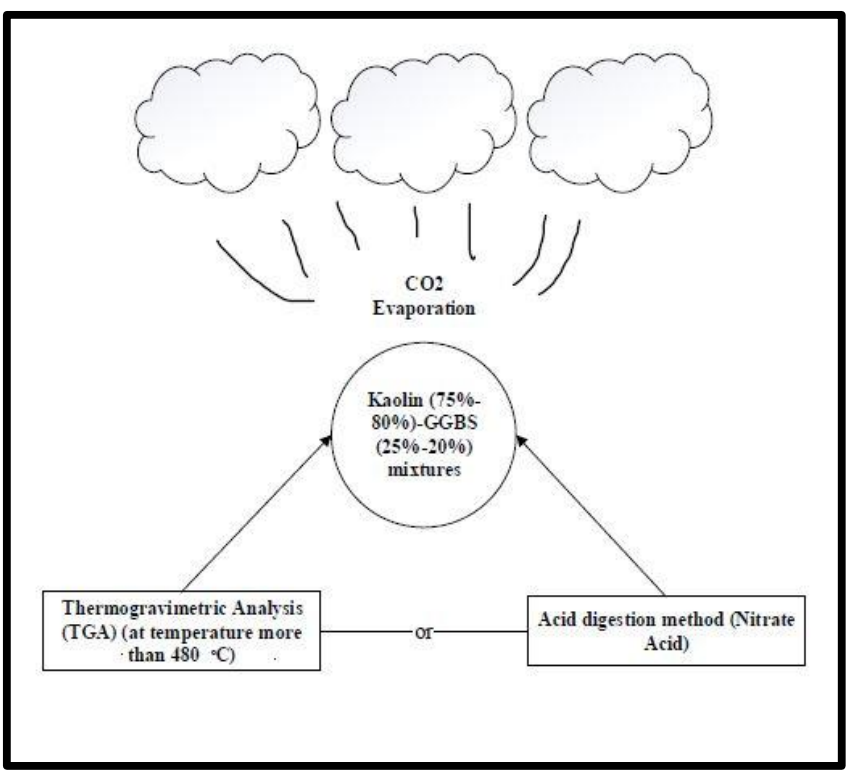

\section{Abstract}

Mineral carbonation has been utilised extensively worldwide as the most important way of permanently sequestering carbon dioxide $\left(\mathrm{CO}_{2}\right)$. This study objective includes sequestering of $\mathrm{CO}_{2}$ gas from atmosphere via carbonation of magnesium and calcium. Waste materials such as ground granulated blast furnaces slag (GGBS) extracted through iron manufacturing as well as brown kaolin mixtures were employed. Acid digestion method as well as thermogravimetric analysis were employed to quantify $\mathrm{CO}_{2}$ sequestered by GGBS-kaolin mixtures. The outcomes indicated that the acid digestion technique is more dependable compared to TGA in measuring $\mathrm{CO}_{2}$. Nonetheless, both methods deduced that the quantity of $\mathrm{CO}_{2}$ sequestered is about $5 \%$ from the total dry mass of the mixtures. Thus, GGBS-kaolin mixtures effectively sequester a substantial quantity of $\mathrm{CO}_{2}$.

Keywords: Kaolin clay, ground granulated blast-furnaces slag, carbon dioxide, acid digestion method, thermogravimetric analysis.

\section{Introduction}

Global warming is considered a key ecological issue affecting the socio-ecological condition of the Earth. Persistent action is required for eliminating the factors that give rise to global warming. Otherwise, the climate's impact would reach a severe and dangerous level, which will affect both nature and humans (Rajanen and Rajanen, 2019). Changes in the environment include raised sea level and temperatures, acidification of oceans, and global reduction in ice thickness. The core cause of global warming is the rise in greenhouse gas concentration (GHG) in the air. Carbon dioxide $\left(\mathrm{CO}_{2}\right)$ is one of the dominant gases in a GHG (Galina et al., 2019). The allowable amount of $\mathrm{CO}_{2}$ in the atmosphere is 350 ppm (Rahman et al., 2017). About $77 \%$ of greenhouse gas concentration originates from $\mathrm{CO}_{2}$, while its composition in the air is about $400 \mathrm{ppm}$ (ppm=part per million). This indicates that $\mathrm{CO}_{2}$ has to be reduced.

Globally, the annual release of $\mathrm{CO}_{2}$ increased to 32.1 billion tonnes in 2015 from 17.78 billion tonnes in 1980 . The rise is about $100 \%$ in 35 years, and it is expected to double by 2035. In Malaysia, $\mathrm{CO}_{2}$ release increased by $69 \%$ during 2000 to 2020 to about 285.7 million tonnes (Jorat et al., 2018). Cement is termed the largest source of $\mathrm{CO}_{2}$ release, led by the disintegration of carbonates. It is also associated with the release of nitrogen oxide, which causes air pollution (Latifi and Meehan, 2017). The overall manufacturing of cement worldwide is accountable for about $7 \%$ of the total release of $\mathrm{CO}_{2}$ (Abdullah et al., 2018). Production of one tonne of cement leads to a release of 0.8 to1.0 tonnes of $\mathrm{CO}_{2}$ (Abdullah et al., 2018; Latifi and Meehan, 2017).

Carbon Capture and Utilization (CCU) intends not just to decrease the quantity of emissions into the atmosphere but also to attain a gain by using $\mathrm{CO}_{2}$ in different kinds of industrial processes, substituting traditional raw materials (Mohsin et al., 2020). CCU has more and more concentrated on transforming $\mathrm{CO}_{2}$ into carbon-based, economically feasible fuel and feedstock. This is not only due to economic reasons but also because such products can decrease the usage of their equivalents based on fossil 
fuels (Mohsin et al., 2020). The sequestered $\mathrm{CO}_{2}$ can be utilised for several applications like feedstock for manufacturing plastic items (Arning et al., 2020), drawing out of compounds with supercritical $\mathrm{CO}_{2}\left(\mathrm{scCO}_{2}\right)$, water treatment, dry cleaning, and food industry applications. For the food sector, $\mathrm{CO}_{2}$ is used as a substitute for the toxic elements utilised for food decontamination. In biological applications, it is utilised for fast growing biomass. CCU technologies are split into four classes: Chemicals from $\mathrm{CO}_{2}, \mathrm{CO}_{2}$ as a solvent, Fuels from $\mathrm{CO}_{2}$, and Enhanced Oil Recovery (EOR) \& Enhanced Coal Bed Methane (ECBM) (Baena-Moreno et al., 2019).

Carbon capture and storage (CCS) technologies are deployed for reducing the quantity of $\mathrm{CO}_{2}$ in the atmosphere using three different methods (Saran et al., 2018). The first is ocean storage with a projected volume of $1000 \mathrm{Gt}$. However, its ecological effect (alteration of ocean chemistry, $\mathrm{pH}$ reductions) has been a drawback. The second is geological stowage with a capacity of 500 to 3000 Gt. The key drawback is the likely leakage of $\mathrm{CO}_{2}$ and the fact that nations such as Korea lack adequate area for geological sequestration (Mun and Cho, 2013).

The third technique is mineral carbonation. This is termed as a substitute for geological storage. In mineral carbonation, $\mathrm{CO}_{2}$ gas is allowed to react with magnesium as well as calcium silicates. The products related to this reaction are silica and carbonate (Prigiobbe et al., 2009). Under ambient conditions, magnesium and calcium carbonates remain thermodynamically stable when they are not contacted with any of the acids (Eloneva et al., 2008). A permeant reaction occurs between calcium or magnesium with $\mathrm{CO}_{2}$ and needs an extended time (Mun and Cho, 2013). This process is fast-tracked by raising the concentration or pressure of $\mathrm{CO}_{2}$ as well as raising the temperature (Mo and Panesar, 2012). One more benefit of calcium and magnesium carbonation is improvement in soil strength (Cai et al., 2015; Cai and Liu, 2017; Cao et al., 2017; Guang-hua et al., 2015; Ho et al., 2017; Liu et al., 2017; Nakarai and Yoshida, 2015; Song-yu et al., 2017; Yi et al., 2013a; Yi et al., 2013b; Yi et al., 2013; Yi et al., 2016).

To sequester $\mathrm{CO}_{2}$, calcium- or magnesium-rich materials are combined with various soil types while also improving soil strengths. To store $\mathrm{CO}_{2}$ in the form of minerals carbonate, reactive magnesia (magnesium-rich material) are combined with various types of soils like sandy soil (Yi et al., 2013) and silty soil (Cai et al., 2015; Guang-hua et al., 2015). A magnesium-rich material is olivine, which is combined with clayey soil for strength improvement when sequestering $\mathrm{CO}_{2}$ (Fasihnikoutalab et al., 2016). Cement was blended with silica sand (Nakarai and Yoshida, 2015). Majority of the earlier findings overlooked the amount of $\mathrm{CO}_{2}$ sequestered within such combination, as these focussed only on the strength gained because of carbonation. Apart from Liu et al. (2017), when various types of soil were combined with $20 \%$ reactive magnesia (from soils dry weight), the amount of $\mathrm{CO}_{2}$ that has been sequestered within those mixture was found to lie in the range of $8 \%-16 \%$ from the mixture dry weight.
For materials that contain sufficient amount of magnesium and calcium for mineral carbonation, the by-product material, ground granulated blast furnaces slag (GGBS), from steel manufacturing contains high $\mathrm{CaO}$ content as well as a considerable amount of MgO. GGBS enjoys a benefit over other material (cement, reactive magnesia, and olivine) since it is a sustainable material which does not cause the release of high quantity of $\mathrm{CO}_{2}$ during production. This paper concentrates on the amount of $\mathrm{CO}_{2}$ sequestered within the ground granulated blast furnaces slag-kaolin mixtures that have been carbonated under various conditions. Kaolin is regarded to possess low strength along with relatively high compressibility feature; therefore, it entails stabilisation prior to construction. Two methods are employed to quantify the amount of $\mathrm{CO}_{2}$ that has been sequestered in GGBS-kaolin mixtures; the acid digestion and thermogravimetric analysis (TGA).

\section{Materials and methods}

The soil taken in use was somewhat acidic and brown kaolin, which was brought from Kaolin (Malaysia) Sdn Bhd plant situated in Tapah, Perak, Malaysia. The GGBS was brought from a local factory situated in Johor Bahru, Johor, Malaysia. The physical characteristics of kaolin and GGBS are displayed in Table 1, whereas the chemical structure of both is shown in Table 2.

Table 1. Properties of kaolin and GGBS

\begin{tabular}{ccc}
\hline Material & Kaolin & GGBS \\
\hline Liquid limit (\%) & 40.5 & 36.6 \\
\hline Plastic limit (\%) & 22.5 & - \\
\hline Plasticity limit (\%) & 18 & - \\
\hline Clay (\%) & 0.65 & 1.876 \\
\hline Silt (\%) & 92.6 & 98.124 \\
\hline Sand (\%) & 6.75 & 0 \\
\hline Specific gravity & 2.52 & 2.83 \\
\hline $\begin{array}{c}\text { Optimum moisture content (\%) } \\
\text { (OMC) }\end{array}$ & 18 & - \\
\hline $\begin{array}{c}\text { Maximum dry density (kg/m }{ }^{3} \text { ) } \\
\text { (MDD) }\end{array}$ & 1640 & - \\
\hline UCS (kPa) & 115 & - \\
\hline $\mathrm{pH}$ & 4.33 & 10.6 \\
\hline
\end{tabular}

The GGBS content in the blend was $20 \%$ and $25 \%$ of total dry amount of kaolin. The mixtures were properly mixed to confirm a consistent mixture, and further $18 \%$ of distilled water was mixed with this blend (OMC). The samples were blended again and then put into a cylinder mould having 38 $\mathrm{mm}$ diameter and $76 \mathrm{~mm}$ height. All of the samples were compressed to attain the MDD (the samples were formulated with the MDD and OMC for raw kaolin). Two groups of samples were made; the first one was put in a humidity chamber having a temperature range (of $27 \pm 2^{\circ} \mathrm{C}$ ) for 7 days before carbonation, therefore it allowed GGBS to hydrate and separate more $\mathrm{CO}_{2}$. Another set was put in the carbonation cell right after demoulding; the working details of the experiment are shown in the Table 3.

The process of carbonation begins after filling the carbonation cell with the sample (triaxial test cell which is attached to a gas cylinder of $\left.99 \% \mathrm{CO}_{2}\right)$. The cell was fastened properly to makes sure that there is no leakage. 
The gas regulator was kept at 200 or $100 \mathrm{kPa}$. The inflow was released to allow $\mathrm{CO}_{2}$ to enter the cell, the outflow was released for 5 minutes to take out the air present inside the cell and let the cell get fully saturated with $\mathrm{CO}_{2}$. After 5 minutes, the valve of the outflow was closed whereas the valve of the inflow was left open for a definite period $(1,3$, 6,24 hours). Following the process of carbonation, the samples were taken out of the cell, put in the kiln for 24 hours, then compacted and sieved through $2 \mathrm{~mm}$ openings. Only particles having diameter less than $2 \mathrm{~mm}$ were utilised for acid digestion and TGA (thermogravimetric analysis) methods. The trial samples for both the techniques are shown in Table 3.

Table 2. Chemical composition of GGBS and kaolin

\begin{tabular}{ccccccc}
\hline Chemical composition & $\mathrm{SiO}_{2}$ & $\mathrm{Al}_{2} \mathrm{O}_{3}$ & $\mathrm{Fe}_{2} \mathrm{O}_{3}$ & $\mathrm{CaO}$ & $\mathbf{M g O}$ & $\mathbf{K}_{2} \mathbf{O}$ \\
\hline GGBS & $30.5 \%$ & $10.4 \%$ & $0.30 \%$ & $47.6 \%$ & $4.88 \%$ & $0.317 \%$ \\
\hline $\begin{array}{c}\text { Kaolin (Saeeda et al., } \\
\text { 2015) }\end{array}$ & $49.5 \%$ & $30.31 \%$ & $1.02 \%$ & $0 \%$ & $0 \%$ & $8.78 \%$ \\
\hline
\end{tabular}

Table 3: Experimental work details for the carbonation process

\begin{tabular}{|c|c|c|c|c|c|c|c|c|}
\hline \multirow{3}{*}{$\begin{array}{c}\text { Content of GGBS (\%) } \\
\text { Curing period (days) } \\
\mathrm{CO}_{2} \text { pressure (kPa) }\end{array}$} & \multicolumn{4}{|c|}{20} & \multicolumn{4}{|c|}{25} \\
\hline & \multicolumn{2}{|c|}{0} & \multicolumn{2}{|c|}{7} & \multicolumn{2}{|c|}{0} & \multicolumn{2}{|c|}{7} \\
\hline & 100 & 200 & 100 & 200 & 100 & 200 & 100 & 200 \\
\hline Carbonation period (hours) & - & - & - & - & - & - & - & - \\
\hline 1 & $\sqrt{ }$ & V & V & $\mathrm{V}$ & $\mathrm{V}$ & $\mathrm{V}$ & $\mathrm{V}$ & V \\
\hline 3 & $\sqrt{ }$ & $\mathrm{V}$ & $\mathrm{V}$ & $\sqrt{ }$ & $\mathrm{V}$ & $\sqrt{ }$ & $\mathrm{V}$ & V \\
\hline 6 & $\mathrm{~V}$ & $\sqrt{ }$ & $\mathrm{V}$ & $\mathrm{V}$ & $\mathrm{V}$ & $\mathrm{V}$ & $\mathrm{V}$ & $\mathrm{V}$ \\
\hline 24 & $\sqrt{ }$ & $\mathrm{V}$ & V & $\mathrm{V}$ & $\mathrm{V}$ & $\mathrm{V}$ & $\sqrt{ }$ & $\mathrm{V}$ \\
\hline
\end{tabular}

Solution of $10 \%$ nitrate acid was used for the acid digestion method. Approximately 40 grams of the selected soil was placed in a $600 \mathrm{ml}$ mug, prior to which the weight of empty beaker with glass rod was recorded. $300 \mathrm{ml}$ of $10 \%$ nitrate acid solution was put in another beaker whose weight was measured and logged. The weighed solution was mixed with the soil; $\mathrm{CO}_{2}$ bubbles then emerged on the outside. The concoction was mixed together for ten minutes using the glass rod (until the bubbles vanished). Last of all, the weight of soil, beaker, glass rod, and the $\mathrm{HNO}_{3}$ solution was logged, and the following equation was applied to calculate the amount of $\mathrm{CO}_{2}$ sequestered in the processed kaolin.

$$
\mathrm{CO}_{2}=\frac{m_{1}+m_{2}-m_{3}}{m_{1} /\left(1+w_{\mathrm{f}}\right)} * 100
$$

where $m_{1}=$ sieve carbonated kaolin (40 gm approximately), $m_{2}=$ nitrate acid solution (300 gm approximately), $m_{3}=$ mixture weight after 10 minutes of continuous stirring, $W_{\mathrm{f}}=$ the gravimetric water content of carbonated soil.

TGA analysis was performed based on ASTM E1131 - 08. Graphs of both the DTA (differential thermal analysis) and TGA were employed for evaluation. The assessment was carried out in nitrogen (N2) environment, the first sample mass was logged, and then it was heated at the rate of $20^{\circ} \mathrm{C}$ /Min. The weight of the sample was logged at the end of every minute.

\section{Results and discussion}

\subsection{Acid digestion method}

The method of acid digestion consists of the chemical reaction between magnesium or calcium carbonate yield and acid wherein the $\mathrm{CO}_{2}$ evaporates and returns to the atmosphere. An exothermic reaction takes place which includes the formation of magnesium or calcium nitrate, water, and there was also the formation of $\mathrm{CO}_{2}$ gas as foams. The $10 \%$ nitrate acid $\left(\mathrm{HNO}_{3}\right)$ solution was used in this study.

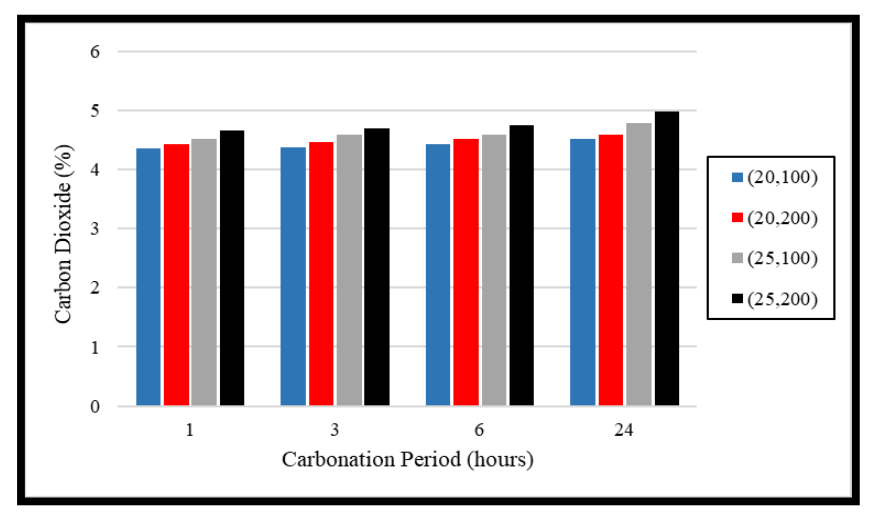

Figure 1. Amount of $\mathrm{CO}_{2}$ sequestered by kaolin-GGBS mixture at 0 days curing carbonated under different conditions using acid digestion method

Figures 1 and 2 show the $\mathrm{CO}_{2}$ amount isolated by the processing of kaolin with GGBS for durations of 0-day and 7-days carbonation process under separate conditions using the method of acid digestion, respectively. The tag ( $A$, B) represents the kaolin processed with $A$ GGBS amount and under $\mathrm{B} \mathrm{CO}_{2}$ applied pressure.

Results from Figure 1 state that the $\mathrm{CO}_{2}$ amount isolated from the processed kaolin with GGBS $20 \%$ and $25 \%$ ranges from 4 to $5 \%$ in comparison to its original weight. In such cases, a sample $(20,100)$ processed for 0 days and given carbonation treatment for 1-hour isolate approximately $4.35 \% \mathrm{CO}_{2}$ which rises to $4.42 \%$ after 6 hours of carbonation and keeps rising until it reaches $4.51 \%$ after one day of carbonation process. The amount of $\mathrm{CO}_{2}$ for sample $(20,200)$ with the same carbonation durations is slightly higher in comparison to the sample $(20,100)$. 
Sample $(25,100)$ separates about $4.51 \% \mathrm{CO}_{2}$ at the end of 1 hour of carbonation, and thus increases to $4.59 \%$ following 6 hours carbonation; further reaches $4.79 \%$ after 24 hours of carbonation.

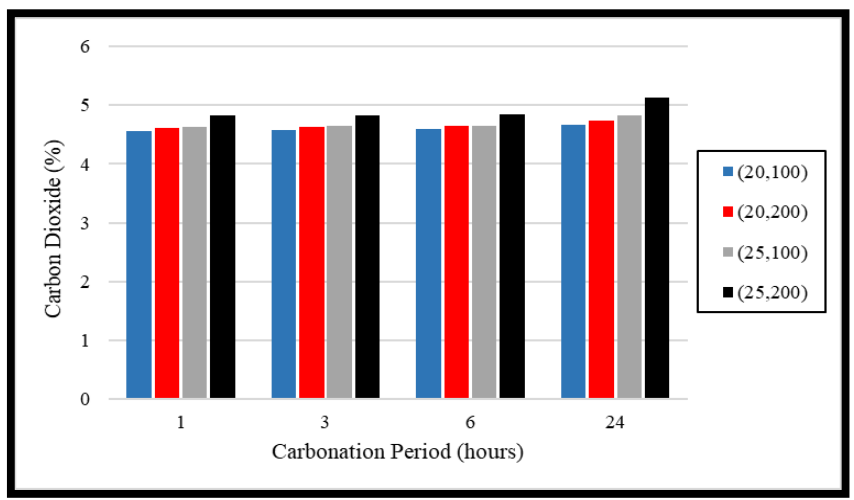

Figure 2. Amount of $\mathrm{CO}_{2}$ sequestered by kaolin-GGBS mixture at 7 days curing carbonated under different conditions using acid digestion method

Figure 2 shows the amount separated by the processing of GGBS-kaolin mixture for 7 days and carried out carbonation process with 100 and $200 \mathrm{kPa} \mathrm{CO} 2$ pressure for a duration of 24 hours. The result resembles that of Figure 1 wherein the $\mathrm{CO}_{2}$ amount in the soil increases as time progresses and with the increase in the applied pressure amount. For example, in the sample $(20,100)$, there is formation of about $4.56 \% \mathrm{CO}_{2}$ after an hour's carbonation which keeps increasing slightly and gets $4.6 \%$ and $4.67 \%$ after 6 - and 24 hours carbonation, respectively. Then again, for sample $(20,100)$, there is a slight increase in the values as it reaches $4.61 \%, 4.65 \%$, and $4.73 \%$ after 1,6 , and 24 hours of carbonation, respectively.

There is essentially no noteworthy difference between the amount sequestered at the 1 st hour, and that sequestered after 24 hours; most of the $\mathrm{CO}_{2}$ sequestration occurs during the 1st-hour of the carbonation process. The outcome resembles earlier results (Cai and Liu, 2017; Yi et al., 2016) in which the $\mathrm{CO}_{2}$ amount increases gradually. The result showed a pattern similar to the UCS outcome; the rate of the isolation of $\mathrm{CO}_{2}$ is proportional to the strength development.

\subsection{Thermogravimetric (TGA) analysis}

TGA assessment was conducted alongside acid digestion technique in order to quantify the weight loss caused by heating. Also, computation of the amount of $\mathrm{CO}_{2}$ was done. Weight loss as well as differential thermal analysis (DTA) with increase in temperature have been shown in Figures 3 to 6.

The decomposition was carried out for well-crystallised $\mathrm{CaCO}_{3}$ and amorphous $\mathrm{CaCO}_{3}$ in the temperature range of $780-990^{\circ} \mathrm{C}$ and $550-780^{\circ} \mathrm{C}$, respectively. However, due to the stabilisation, distinguishing between the actual carbonated material from the raw material versus the carbonated material is not possible. Thus, we can overlook the amount of carbonated material from the raw material. Post $480^{\circ} \mathrm{C}$, the sample's weight loss could be due to the decarbonation of calcium and magnesium (Cai and Liu, 2017; Liu et al., 2017).

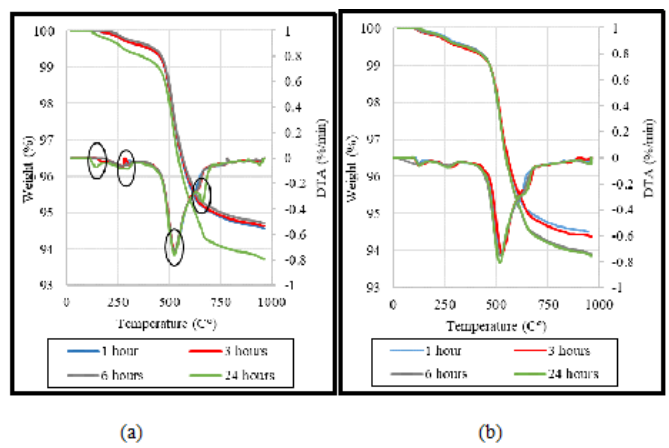

Figure 3. TGA and DTA curves of carbonated $20 \%$ GGBS treated kaolin at 0 days curing carbonated with (a) $100 \mathrm{kPa}$ (b) $200 \mathrm{kPa}$

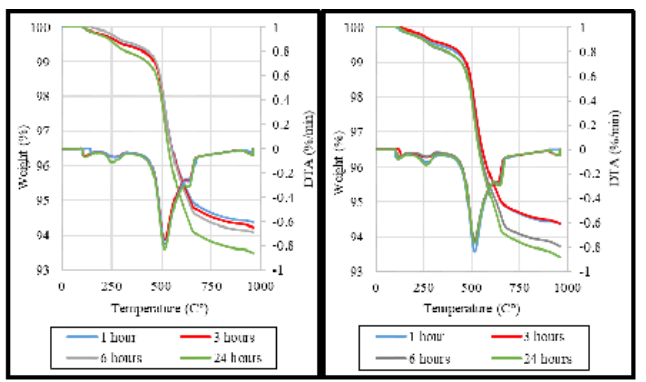

(a)

(b)

Figure 4. TGA and DTA curves of carbonated $25 \%$ GGBS treated kaolin at 0 days curing carbonated with (a) $100 \mathrm{kPa}$ (b) $200 \mathrm{kPa}$

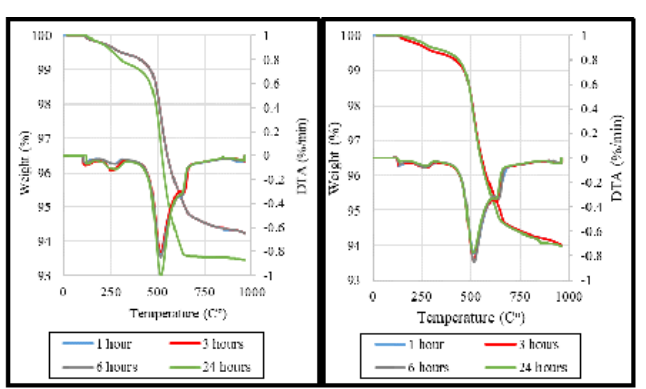

(a)

(b)

Figure 5. TGA and DTA curves of carbonated $20 \%$ GGBS treated kaolin at 7 days curing carbonated with (a) $100 \mathrm{kPa}$ (b) $200 \mathrm{kPa}$

Figures 3 to 6 display the curves for TGA and DTA pertaining to carbonated GGBS with different $\mathrm{CO}_{2}$ pressure processed kaolin that has been treated for 0 and 7 days. As per the TGA assessment, a decrease in the weight is caused by the increase in temperature. Once the temperature reaches $850^{\circ} \mathrm{C}$, every sample loses around $6 \%-6.5 \%$ weight versus its original weight. At temperatures $450-850^{\circ} \mathrm{C}$, majority of the weight loss occur. For all samples, the pattern of weight loss is almost similar, and this could be clearly seen bases on the DTA assessment.

As displayed in Figure 3a, the DTA graphs have been represented with four peaks, along with the change in temperature $\left(0^{\circ} \mathrm{C}\right.$ to $\left.850^{\circ} \mathrm{C}\right)$. Due to loss of bound water, at $0^{\circ} \mathrm{C}$ to $250^{\circ} \mathrm{C}$, the first small peak is seen to appear. This may also show the nesquehonite's transformation to dypingite or hydromagnesite, since at temperatures $\geq 50 \mathrm{C}$, nesquehonite loses stability. Occurrence of a small peak is 
seen when the UCS sample was kept in the oven for 24 hours to measure the water content, and due to the presence of small amount of nesquehonite in the sample. The second peak, which exists between temperatures of $250^{\circ} \mathrm{C}$ and $480^{\circ} \mathrm{C}$, represents the dehydroxylation of calcium hydroxide $\left(\mathrm{Ca}(\mathrm{OH})_{2}\right)$ and brucite $\left(\mathrm{Mg}(\mathrm{OH})_{2}\right)$ that are yet to be carbonated (Unluer and Al-tabbaa, 2013). The second peak's size as well as the considerably small weight loss specify that most of the calcium and magnesium have been carbonated as well as a reaction with $\mathrm{CO}_{2}$, that results in just a small amount of uncarbonated residue.

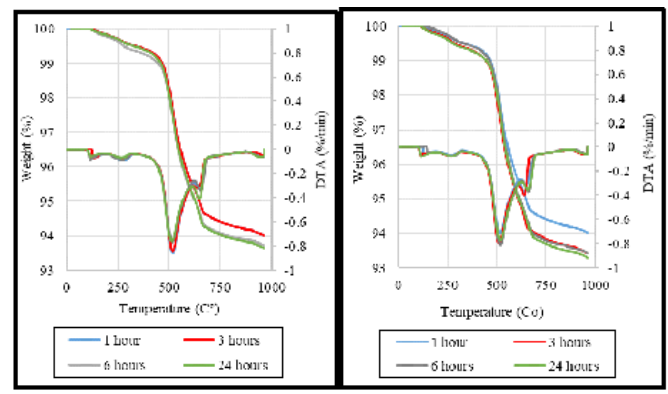

(a)

(b)

Figure 6. TGA and DTA curves of carbonated $25 \%$ GGBS treated kaolin at 7 days curing carbonated with (a) $100 \mathrm{kPa}$ (b) $200 \mathrm{kPa}$

Between $480^{\circ} \mathrm{C}$ and $850^{\circ} \mathrm{C}$, the relatively large fourth and third peaks are an outcome of decarbonisation of $\mathrm{Ca}$ and $\mathrm{Mg}$ carbonated products (here, $\mathrm{CO}_{2}$ is sent back to the atmosphere). These peaks can be clearly distinguished versus the first and second peaks. The amount of $\mathrm{CO}_{2}$ segregation is displayed in the graph based on the weight loss observed at temperatures of $480^{\circ} \mathrm{C}$ and $850^{\circ} \mathrm{C}$.

Figures 7 and 8 display the amount of $\mathrm{CO}_{2}$ that has been sequestered by the GGBS-kaolin mixture via TGA. The label $(20,100)$ specifies $20 \%$ GGBS treated kaolin that has been carbonated at $100 \mathrm{kPa} \mathrm{CO} 2$ applied pressure. Here, identical behaviours were observed in both the figures. The mixture composition includes $4.3 \%$ to $5.2 \% \mathrm{CO}_{2}$ pertaining to the soil's overall dry mass. This is almost identical to the estimated amount based on the acid digestion technique.

The amount of $\mathrm{CO}_{2}$ sequestered in the soil is affected by several factors, such as amount of calcium and magnesium available, $\mathrm{CO}_{2}$ applied pressure for acceleration, curing period before to the carbonation process as well as carbonation time. In this study, the impact of these four factors has been analysed. Extension in the carbonation period was found to result in increase in $\mathrm{CO}_{2}$ amount. Eventually, at a certain point, the soil achieves its maximum capacity, thus halting the sequestration.

As shown in Figures 7 and 8, on employing $200 \mathrm{kPa} \mathrm{CO} 2$ for identical condition, the amount of $\mathrm{CO}_{2}$ sequestered was found to be marginally higher versus on employing $100 \mathrm{kPa}$ $\mathrm{CO}_{2}$. Applying higher $\mathrm{CO}_{2}$ pressure led in an increment in the pore solution acidity. This resulted in release of additional magnesium and calcium ions for carbonation (Fasihnikoutalab et al., 2016; Mo and Panesar, 2012), which consequently led to more $\mathrm{CO}_{2}$ absorption. Furthermore, a longer curing period (i.e., 7 days) enabled sequestration of
$\mathrm{CO}_{2}$ as it allowed a higher amount of $\mathrm{CO}_{2}$. The magnesium and calcium hydrates due to 7 days of curing helped form $\mathrm{Mg}(\mathrm{OH})_{2}$ and $\mathrm{Ca}(\mathrm{OH})_{2}$, respectively, which resulted in formation of additional carbonation products.

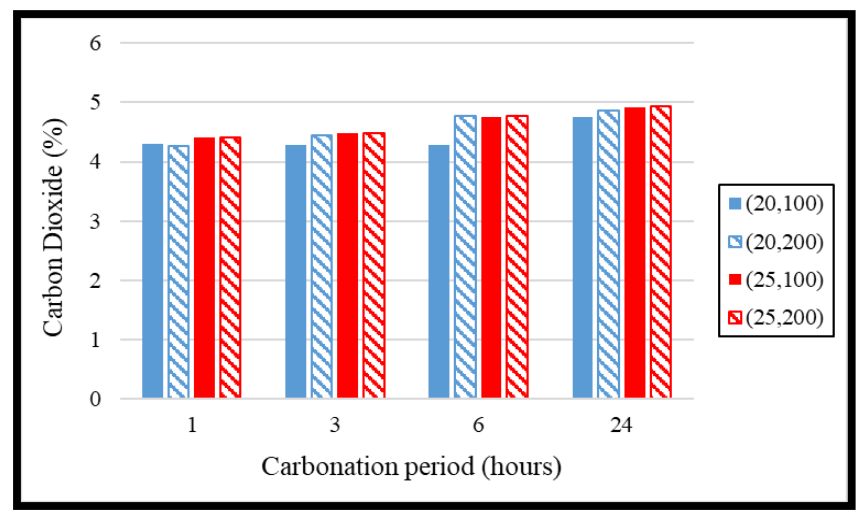

Figure 7. Amount of $\mathrm{CO}_{2}$ sequestered by kaolin-GGBS mixture at 0 days curing carbonated under different conditions using TGA analysis

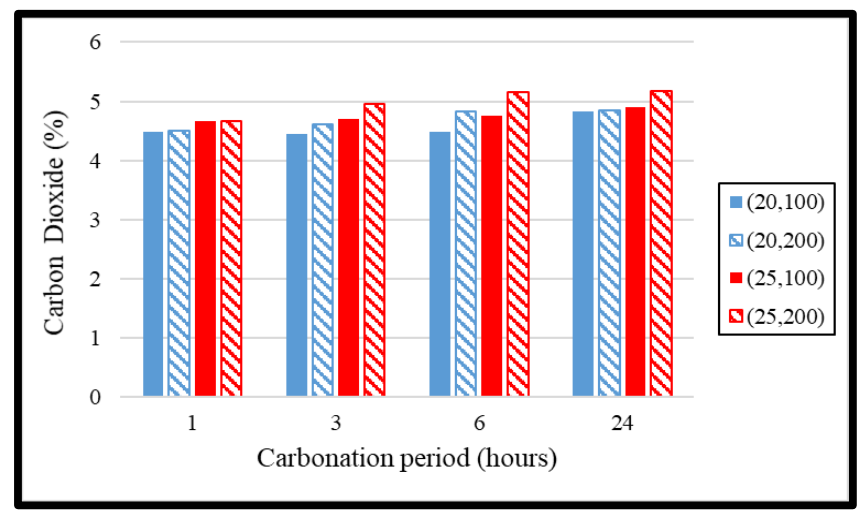

Figure 8. Amount of $\mathrm{CO}_{2}$ sequestered by kaolin-GGBS mixture at 0 days curing carbonated under different conditions using TGA analysis

The most critical parameter that regulates the $\mathrm{CO}_{2}$ amount in the soil is the amount of available calcium and magnesium in the chemical composition of the mixture. It also helps control other factors as discussed previously. As per the findings, it was found that more $\mathrm{CO}_{2}$ can be captured with 1 gram of magnesium versus 1 gram of calcium. In addition, as large amounts of magnesium and calcium are available, more $\mathrm{CO}_{2}$ is captured by $25 \%$ GGBSkaolin mixture versus 20\% GGBS-kaolin mixture (Cai and Liu, 2017).

As per this study, about $5 \% \mathrm{CO}_{2}$ was captured by kaolin$25 \%$ GGBS mixture; however, this is not regarded as the maximum capacity of the mixture. In addition, the chemical composition of kaolin did not include any traces of calcium or magnesium, and hence the presence of GGBS causes sequestering of $\mathrm{CO}_{2}$. Thus, in conclusion, GGBS with $4.9 \%$ magnesium and $47.5 \%$ calcium can capture around $20 \%$ $\mathrm{CO}_{2}$ from its dry weight.

When this method of acid digestion was compared with the thermogravimetric analysis, identical volume of the $\mathrm{CO}_{2}$ that has been sequestered in the treated soil was found. 
However, compared with TGA analysis, such type of acid digestion method is regarded to be more reliable when it comes to quantification of $\mathrm{CO}_{2}$. This could be due to the following two reasons: first, usage of inhomogeneous powder in TGA analyses, which may not signify each sample, and second, high volatility of nitrate acid could have resulted in the release of large quantities of heat during the process of digestion amongst the acid as well as treated Kaolin (Liu et al., 2017). In this method of acid digestion, the employed mass of the soil was found to be around $40 \mathrm{~g}$, or $25 \%$ of the UCS sample mass in total, compared to just $10 \mathrm{~g}$ pertaining to the sample used for TGA analyses.

The $\mathrm{CO}_{2}$ sequestration based on carbonation of GGBSkaolin mixtures is regarded to be significant. For future work, greater than $25 \%$ GGBS can be added to kaolin as it is regarded to sequester additional $\mathrm{CO}_{2}$. Mixing of other various types of soil could be done with GGBS in order to establish the role played by the soil during the carbonation process. An alternative approach (by-products and waste material rich with calcium and magnesium) to substitute GGBS can be identified as this would also be beneficial for recycling and managing of waste.

\section{Conclusion}

This study objective includes determination of GGBS' ability to stabilise soil as well sequester carbon dioxide simultaneously. The following conclusion can be drawn:

1. As per the TGA analysis as well as acid digestion method, it was revealed that the quantity of $\mathrm{CO}_{2}$ that was sequestered within the GGBS-kaolin carbonation mixture was in the range of $4.3 \%-5 \%$ with regards to the mix's dry mass.

2. With rise in the content of GGBS in the mixture, the amount of $\mathrm{CO}_{2}$ that has been sequestered within the kaolin-GGBS mixture was also found to increase.

3. More $\mathrm{CO}_{2}$ was yielded with the samples that were left for curation for 7 days prior to carbonation in order to allow hydration of GGBS storage versus the samples that were placed directly under the carbonation cell.

4. Appling $200 \mathrm{kPa} \mathrm{CO} 2$ pressure results in sequestration of additional $\mathrm{CO}_{2}$ when compared with applying 100 $\mathrm{kPa} \mathrm{CO}_{2}$ pressure. This can be attributed to the increment in the pore solution acidity when applying greater $\mathrm{CO}_{2}$ pressure. This results in release of additional magnesium and calcium ions for carbonation, thus resulting in sequestering of additional $\mathrm{CO}_{2}$.

5. Compared with TGA analysis, the acid digestion method is regarded to be more reliable when it comes to quantification of $\mathrm{CO}_{2}$. This can be attributed to the following reasons: high volatility pertaining to nitrate acid that results in the release of large quantities of heat during the digestion process, the inhomogeneous powder employed in TGA analysis and the higher amount of sample employed in acid digestion method (10 grams for
TGA and 40 grams for acid digestion method), which help achieve more accurate results.

6. Previous study (Liu et al., 2017) demonstrated that $20 \%$ reactive magnesia, when mixed with various soil type, would capture almost $8 \%-16 \% \mathrm{CO}_{2}$ from the mixture dry mass. This was found to be higher versus the current study $(4.3 \%-5 \%)$, because of larger content of $\mathrm{MgO}$ in reactive magnesia $(80 \%-$ $90 \%$ ) versus $\mathrm{GGBS}(\mathrm{CaO}=47 \%$ and $\mathrm{MgO}=4.88 \%)$, which results in additional $\mathrm{CO}_{2}$ sequestration. There are two benefits associated with GGBS when compared with reactive magnesia: first, it being a sustainable material, and second, reactive magnesia production results in higher $\mathrm{CO}_{2}$ emission versus GGBS.

\section{Acknowledgements}

The authors are grateful for the support offered by MOE and UTM with Vote no. FRGS/1/2019/TK10/UTM/02/21

R.J130000.7851.5F197.

\section{References}

Abdullah H., Shahin M. and Sarker P. (2018), Use of fly-ash geopolymer incorporating ground granulated slag for stabilisation of Kaolin Clay cured at ambient temperature, Geotechnical and Geological Engineering, 2. https://doi.org/ 10.1007/s10706-018-0644-2.

Arning K., Offermann-van Heek J., Sternberg A., Bardow A. and Ziefle M. (2020), Risk-benefit perceptions and public acceptance of carbon capture and utilization. Environmental Innovation and Societal Transitions, 35(May 2019), 292-308. https://doi.org/10.1016/j.eist.2019.05.003.

Baena-Moreno F.M., Rodríguez-Galán M., Vega F., Alonso-Fariñas B., Vilches Arenas L.F. and Navarrete B. (2019), Carbon capture and utilization technologies: a literature review and recent advances, Energy Sources, Part A: Recovery, Utilization and Environmental Effects, 41(12), 1403-1433. https://doi.org/10.1080/15567036.2018.1548518.

Cai G. and Liu S. (2017), Compaction and mechanical characteristics and stabilization mechanism of carbonated reactive MgO-stabilized silt, KSCE Journal of Civil Engineering, 21, 2641-2654. https://doi.org/10.1007/ s12205-017-1145-1.

Cai G.H., Du Y.J., Liu S.Y. and Singh D.N. (2015), Physical properties, electrical resistivity, and strength characteristics of carbonated silty soil admixed with reactive magnesia, Canadian Geotechnical Journal, 52, 1699-1713.

Eloneva S., Teir S., Salminen J., Fogelholm C.J. and Zevenhoven R. (2008), Fixation of $\mathrm{CO}_{2}$ by carbonating calcium derived from blast furnace slag, Energy, 33(9), 1461-1467. https://doi.org/10.1016/j.energy.2008.05.003.

Fasihnikoutalab M.H., Asadi A., Huat B.B.K., Ball R.J., Pourakbar S. and Singh P. (2016), Utilisation of carbonating olivine for sustainable soil stabilisation, Journal of Environmental Geotechnics, (February). https://doi.org/10.1680/jenge.15.0 0018.

Galina N.R., Arce G.L.A.F. and Ávila I. (2019), Evolution of carbon capture and storage by mineral carbonation: Data analysis and relevance of the theme, Minerals Engineering, 142(July), 105879. https://doi.org/10.1016/j.mineng.2019.105879. 
Guang-hua C., Song-yu L., Yan-jun D., Ding-wen Z. and Xu Z. (2015), Strength and deformation characteristics of carbonated reactive magnesia treated silt soil, Journal of Central South University, 22, 1859-1868. https://doi.org/10.1007/s11771-015-2705-5.

Jorat M.E., Aziz M., Marto A., Zaini N., Jusoh S.N. and Manning D.A.C. (2018), Sequestration atmosperic $\mathrm{CO}_{2}$ inorganically: $A$ solution for Malaysia's $\mathrm{CO}_{2}$ emission, Geosciences Journal, 8.

Latifi N. and Meehan C.L. (2017), Strengthening of montmorillonitic and kaolinitic clays with calcium carbide residue: A sustainable additive for soil stabilization, Geotechnical Frontiers 2017, 154-163. https://doi.org/10.1061/9780784480441.017.

Liu S., Cai G., Cao J. and Wang F. (2017), Influence of soil type on strength and microstructure of carbonated reactive magnesia- treated soil, European Journal of Environmental and Civil Engineering, 8189(September), 1-19. https://doi.org/10.1080/19648189.2017.1378925.

Mo L. and Panesar D.K. (2012), Effects of accelerated carbonation on the microstructure of Portland cement pastes containing reactive MgO. Cement and Concrete Research, 42(6), 769777. https://doi.org/10.1016/ j.cemconres.2012.02.017.

Mohsin I., Al-Attas T.A., Sumon K.Z., Bergerson J., McCoy S. and Kibria M.G. (2020), Economic and environmental assessment of integrated carbon capture and utilization, Cell Reports Physical Science, 1(7), 100104. https://doi.org/10.1016/j.xcrp.2020.100104.

Mun M. and Cho H. (2013), Mineral carbonation for carbon sequestration with industrial waste, Energy Procedia, 37, 6999-7005. https://doi.org/10.1016/j.egypro.2013.06.633

Nakarai K. and Yoshida T. (2015), Effect of carbonation on strength development of cement-treated Toyoura silica sand, Soils and Foundations, 55(4), 857-865. https://doi.org/10.1016/j.sandf.2015.06.016.

Prigiobbe V., Hänchen M., Werner M., Baciocchi R. and Mazzotti M. (2009), Mineral carbonation process for $\mathrm{CO}_{2}$ sequestration. Energy Procedia, 1, 4885-4890. https://doi.org/10.1016/j.egypro.2009.02.318.

Rahman F.A., Aziz M.M.A., Saidur R., Bakar W.A.W.A., Hainin M.R., Putrajaya R. and Hassan N.A. (2017), Pollution to solution: Capture and sequestration of carbon dioxide $\left(\mathrm{CO}_{2}\right)$ and its utilization as a renewable energy source for a sustainable future. Renewable and Sustainable Energy Reviews, 71(January), 112-126. https://doi.org/10.1016/ j.rser.2017.01.011.

Rajanen D. and Rajanen M. (2019), Climate change gamification : A literature review. In In Proc. of Gamifin 2019 Conference. pp. 253-264. Retrieved from http://ceur-ws.org/Vol-2359/ paper22.pdf.

Saeeda K.A.H., Kassima K.A., Yunusa N.Z.M. and Nur H. (2015), Physico-Chemical Characterization Of Lime Stabilized Tropical Kaolin. Jurnal Teknologi, 72(3), 83-90.

Saran R.K., Arora V. and Yadav S. (2018). $\mathrm{CO}_{2}$ sequestration by mineral carbonation: a review. Global NEST Journal, 20(3), 497-503. Retrieved from https://doi.org/10.30955/gnj. 002597.

Song-yu L., Guang-hua C., Yan-jun D., Heng Z. and Ping W. (2017), Engineering properties of carbonated reactive magnesiastabilized silt under different activity index, Procedia
Engineering, 189(May), 158-165. https://doi.org/ 10.1016/j.proeng.2017.05.026.

Unluer C. and Al-tabbaa A. (2013), Impact of hydrated magnesium carbonate additives on the carbonation of reactive $\mathrm{MgO}$ cements, Cement and Concrete Research, 54, 87-97. https://doi.org/10.1016/j.cemconres.2013.08.009.

Yi Y., Liska M., Akinyugha A., Unluer C. and Al-Tabbaa A. (2013a). Preliminary laboratory-scale model auger installation and testing of carbonated soil-MgO columns, Geo-technical Testing Journal, 36(March). https://doi.org/10.1520/ GTJ20120052.

Yi Y., Liska M., Unluer C. and Al-tabbaa A. (2013b), Carbonating magnesia for soil stabilization, Canadian Geotechnical Journal, 50(June), 899-905.

Yi Y., Lu K., Liu S. and Al-tabbaa A. (2016), Property changes of reactive magnesia - stabilized soil subjected to forced carbonation. Canadian Geotechnical Journal, 53, 314-325.

Yi Y.L., Liska M., Unluer C. and Abir A.-T. (2013), Initial investigation into the carbonation of $\mathrm{MgO}$ for soil stabilisation, In Proceedings of the 18th International Conference on Soil Mechanics and Geotechnical Engineering, Vol. 5, pp. 2641-2644. 